\title{
ANALISIS KADAR KOMPONEN KIMIA PELEPAH SAWIT VARIETAS DURA SEBAGAI BAHAN BAKU PULP YANG DITERAPKAN PADA PEMBELAJARAN KIMIA
}

\author{
Sri Astuti ${ }^{*}$, Ridwan Yahya ${ }^{2}$, dan Agus Sundaryono ${ }^{3}$ \\ ${ }^{1,3}$ Pascasarjana Pendidikan IPA FKIP Universitas Bengkulu, Bengkulu \\ ${ }^{2}$ Jurusan Kehutanan Fakultas Pertanian Universitas Bengkulu, Bengkulu \\ *Email: astutyseri@yahoo.co.id
}

\begin{abstract}
ABSTRAK
Penelitian ini bertujuan untuk menentukan kadar komponen kimia yang meliputi zat ekstraktif, lignin, holoselulosa dan $\alpha$-selulosa pelepah sawit varietas dura, menjelaskan pengaruh bagian pelepah sawit varietas dura terhadap kadar ekstraktif, lignin, holoselulosa dan $\alpha$-selulosa, membandingkan perbedaan kadar komponen kimia antar bagian pangkal, tengah dan ujung dari pelepah sawit varietas dura, mengindentifikasi gugus fungsi yang ada pada sampel (lignin, holoselulosa dan $\alpha$-selulosa) dengan menggunakan metode spektroskopi FTIR, membandingkan pengaruh perbedaan hasil belajar sebelum dan sesudah diberi pengembangan konsep makromolekul dengan melihat video yang diaplikasikan pada Lembar Kerja Peserta Didik (LKPD) terhadap cara berfikir kritis siswa Olimpiade Kimia. Zat ekstraktif, holoselulosa, $\alpha$ - selulosa dan lignin dianalisis dengan menggunakan Tappi Test methode :204, T 203, T:222 serta diidentifikasi dengan spektroskopi FTIR. Hasil penelitian Kadar komponen kimia pada pelepah sawit varietas dura menurut bagiannya dari pangkal, tengah, ujung berturut-turut dengan rerata untuk kadar zat ekstraktif $8,92 \%, 7,80 \%, 7,23 \%$. Lignin $24,89 \%, 26,87$ $\%, 24,17 \%$. Holoselulosa 84,11 \%, 83,47 \%, 82,24\% dan $\alpha$ - selulosa 45,76 \%, 45,76 \%, 45,54\%. Penelitian pendidikan dengan desain one-group pretes-postes. Penelitian pendidikan dilakukan dengan melakukan proses pembelajaran menggunakan Video dan LKPD sesuai dengan keterampilan berpikir kritis. Pada implementasi dalam pembelajaran terdapat perbedaan pada hasil belajar kimia sebelum dan sesudah proses pembelajaran menggunakan video dan LKPD. Rata-rata nilai pretest 42,25 sedangkan rata-rata postest sebesar 83,50 dan terdapat peningkatan hasil belajar setelah dilakukan proses pembelajaran menggunakan Video dan LKPD secara signifikan sebesar 41.25.
\end{abstract}

Kata kunci : zat ekstraktif; holoselulosa; $\alpha$-selulosa; lignin; LKPD.

\section{PENDAHULUAN}

Industri pulp dan kertas merupakan salah satu industri yang mengalami perkembangan pesat dalam kurun waktu terakhir ini. Industri ini juga menjanjikan devisa yang besar dan merupakan salah satu komoditi ekspor andalan Indonesia. Indonesia menempati posisi 12 dalam jajaran produsen pulp dunia dengan ekspor 4,1 juta ton di tahun 1998. Sementara itu Amerika Serikat menempati urutan pertama dengan menyumbang 32,6\% pada produksi total pulp dunia. Penggunaan kertas di dunia saat ini telah mencapai angka yang sangat tinggi (Sonnenfeld, 2000).

Menyikapi hal ini pemerintah berencana menjadi produsen pulp dan kertas terbesar dunia (Syafii, 2000).
Permasalahannya adalah, produsen pulp dan kertas di tanah air pada umumnya menggunakan kayu hutan sebagai bahan baku, 90\% pulp dan kertas yang dihasilkan menggunakan bahan baku kayu sebagai sumber bahan berserat selulosa. Dapat diprediksikan bahwa akan terjadi eksploitasi hutan secara besar-besaran apabila kelak Indonesia menjadi produsen pulp terbesar di dunia. Terganggunya kestabilan lingkungan menjadi dampak yang perlu mendapat perhatian khusus (Kartodihardjo \& Supriono, 2000).

Kekurangan bahan baku pulp dan kertas dari bahan baku kayu memaksa pihak industri harus mencari alternatif bahan baku lainnya misalnya dengan menggunakan bahan baku bukan kayu (non wood) seperti limbah. Penggunaan limbah sebagai bahan baku pulp 
dan kertas akan memberikan dampak yang positif yaitu mengurangi dampak pencemaran (limbah) serta dapat memberikan hasil tambahan bagi penghasil limbah tersebut. Limbah pelepah sawit belum dimanfaatkan secara optimal, pelepah sawit hanya dimanfaatkan menjadi pakan ternak (Batubara, 2003, Guntoro, 2008) dan pupuk kompos. Analisis kimia terhadap pelepah sawit menunjukkan bahwa terdapat komponen selulosa, hemiselulosa dan lignin yang memperlihatkan bahwa pelepah sawit berpeluang untuk diolah lebih lanjut menjadi produk yang bermanfaat dan bernilai ekonomis (Harpendi et al. 2012, Anggraini \& Roliadi, 2011).

Bidang studi kimia sebagai salah satu mata pelajaran yang diajarkan di sekolah berfungsi untuk mengembangkan kemampuan berkomunikasi dengan menggunakan bidangbidang dan simbol-simbol serta ketajaman penalaran yang dapat membantu memperjelas dan menyelesaikan permasalahan dalam kehidupan sehari-hari, guru kimia harus mampu mendemonstrasikan dalam penerapan macam-macam metode dan teknik mengajar dalam bidang studi yang diajarkan.

Penggunaan media pembelajaran dalam kegiatan belajar mengajar di kelas dengan menggunakan video merupakan media yang cocok untuk pembelajaran, seperti kelas, kelompok kecil, bahkan satu siswa seorang diri sekalipun kemudian diaplikasikan ke media pembelajaran Lembar Kerja Peserta Didik (LKPD) dapat meningkatkan hasil belajar. Media pembelajaran lembar kerja peserta didik tersebut dapat digunakan untuk kepribadian anak didik yang tak lain adalah kreatifitas. Kelemahan dari pendekatan penggunaan LKPD adalah siswa harus benar-benar siap untuk belajar mandiri.

\section{METODE PENELITIAN}

Jenis Penelitian yang dilakukan adalah penelitian eksperimen laboratorium yang bertujuan untuk mengetahui Analisis kadar komponen kimia pelepah sawit varietas Dura sebagai bahan baku pulp. Dari hasil penelitian eksperimen laboratorium akan dilanjutkan dengan penelitian pengembangan yang bertujuan untuk menghasilkan produk media pembelajaran berupa Video kemudian diaplikasikan ke Lembar Kerja Peserta Didik
(LKPD) lalu diterapkan ke dalam pembelajaran kimia sehingga dapat dijadikan sebagai sumber belajar. Penelitian ini dilaksanakan pada bulan Februari sampai Mei 2017 pelepah sawit diambil dari kebun sawit masyarakat di Pondok Kelapa kabupaten Bengkulu Tengah. Proses penyiapan serbuk dilakukan di Laboratorium Kehutanan Divisi Teknologi Hasil Hutan, Universitas Bengkulu (UNIB), sedangkan identifikasi komponen kimia (lignin, holoselulosa dan $\alpha$ selulosa) mengunakan Fourier Transfor Infrared (FTIR) di lakukan di Laboratorium Kimia ITB, dan penelitian pendidikan dilakukan di SMA N 1 Lais. Populasi penelitian sains adalah pelepah sawit varietas dura, sedangkan populasi penelitian pendidikan adalah siswa kelompok sains Olimpiade Kimia SMA N 1 Lais.

Penelitian ini menggunakan metode penelitian sampling, dengan teknik penentuan sampel dilakukan secara purposif (sengaja). Diambil sebagai sampel penelitian adalah pelepah sawit varietas dura bagian pangkal $(\mathrm{P})$, tengah (T) dan Ujung (U). Untuk mengetahui pengaruh posisi atau bagian pelepah terhadap komponen kimia maka data dianalisis menggunakan analisis sidik ragam program Statistical Product and Service Solution (SPSS). Jika hasil yang diperoleh berpengaruh nyata maka diuji lanjut DMRT dengan taraf 5 $\%$. Untuk mengetahui potensi pemanfaatan pelepah sawit varietas dura sebagai bahan baku pulp berdasarkan kandungan kadar zat ekstraktif, holoselulosa, $\alpha$-selulosa, dan lignin maka data hasil penelitian dibandingkan dengan klasifikasi komponen kimia kayu. Sedangkan lignin dan $\alpha$ selulosa dianalisis lagi dengan menggunakan FTIR (Panshin \& Zeuw. 1980).

Penelitian pendidikan ini dilakukan menggunakan desain eksperimen yaitu OneGroup Pre test-Post test Design, menurut Arikunto (2008) makna dari pre test post test one group before after design adalah desain yang diadakan dengan melakukan penelitian langsung terhadap satu kelompok subjek dengan dua kondisi observasi yang dilaksanakan tanpa adanya kelompok pembanding, sehingga setiap subjek merupakan kelas kontrol untuk dirinya sendiri. Dalam rancangan ini terdapat satu kelompok subjek penelitian yang mendapatkan perlakuan, untuk selanjutnya diberikan pengukuran sebanyak dua kali sebelum dan 
sesudah perlakuan (pre test-post test). Dari data yang diperoleh dari penelitian maka hasil tes sebelum dan sesuhardah diberikan perlakuan akan dibandingkan untuk melihat apakah ada pengaruhnya yang signifikan antara tingkat kemampuan siswa dalam mempelajari materi mengenai makromolekul.

\section{HASIL DAN PEMBAHASAN}

\section{Kandungan Zat Ekstraktif}

Zat Ekstraktif adalah zat yang terlarut dari kayu baik dengan menggunakan pelarut netral seperti air maupun pelarut organik ( benzena, dikhloromethan, eter, alkohol, campuran alkohol dan benzena). Zat ekstraktif yang larut dalam pelarut organik adalah resin, lemak, lilin dan tanin.

Data pada penelitian untuk ringkasan hasil analisis varian (Anova) pengaruh bagian pelepah sawit varietas dura terhadap nilai kadar Ekstraktif disajikan pada tabel 1

Tabel 1. Analisa pengaruh bagian pelepah sawit varietas dura terhadap nilai kadar Ekstraktif

\begin{tabular}{lccrc}
\hline $\begin{array}{l}\text { Sumber } \\
\text { Variasi }\end{array}$ & $\mathrm{db}$ & $\mathrm{KT}$ & $\mathrm{F}_{\text {hitung }}$ & Sig. \\
\hline Bagian & 2 & 2.216 & 414. & .000 \\
$\begin{array}{l}\text { Pelepah } \\
\text { Galat }\end{array}$ & 6 & .005 & & \\
$\begin{array}{l}\text { Total } \\
\text { koreksi }\end{array}$ & 8 & & & \\
\hline
\end{tabular}

Pada Tabel 1. memperlihatkan bahwa ada pengaruh bagian pelepah sawit terhadap kadar ekstraktif. Hasil Uji Anova menunjukkan ada perbedaan kadar ekstraktif antara posisi bagian pada pelepah sawit varietas Dura, selanjutnya dilakukan uji t.

Tabel 2. Pengaruh bagian pelepah sawit varietas dura terhadap nilai kadar Ekstraktif

\begin{tabular}{cc}
\hline Bagian Pelepah & Rerata \\
\hline Pangkal & $8.91^{\mathrm{c}}$ \\
Tengah & $7.68^{\mathrm{b}}$ \\
Ujung & $7.20^{\mathrm{a}}$ \\
\hline Rerata &
\end{tabular}

Ket : nilai rata-rata yang tidak diikuti dengan huruf yang sama berarti berbeda nyata

Pada tabel 2 menunjukkan bagian pelepah antara pangkal, tengah dan ujung memiliki perbedaan nyata menurut uji t pada taraf $5 \%$. Berdasarkan nilai rerata kadar ekstraktif, pelepah bagian pangkal mempunyai kadar ekstraktif yang lebih tinggi dibandingkan pelepah yang terletak dibagian atasnya, dikarenakan semakin tua jaringan semakin banyak sel-sel yang sudah dewasa maka semakin banyak terjadinya pengendapan, sedangkan bagian ujung umumnya disusun dengan sel-sel dengan dinding yang tipis, dimana belum banyak mengalami proses penebalan primer (lignifikasi).

\section{Lignin}

Analisis Lignin Menggunakan FTIR

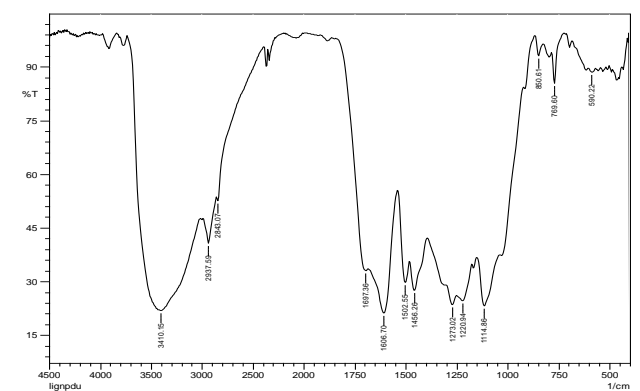

Gambar 1. Lignin Pelepah Sawit Bagian Pangkal menggunakan FTIR

Hasil analisis FTIR lignin pelepah sawit varietas dura terdapat puncak dengan intensitas kuat pada bilangan gelombang $3410,15 \mathrm{~cm}^{-1}$ menunjukkan gugus hidroksil $(-\mathrm{OH})$, pada daerah $2937,59 \mathrm{~cm}^{-1}$ adanya puncak serapan $\mathrm{C}-\mathrm{H}$, kemudian teramati puncak serapan pada $1606,70 \mathrm{~cm}^{-1}$ adanya cincin aromatik ( $\mathrm{C}=\mathrm{C}$ Aromatik).

Tabel 3 Hasil analisis gugus fungsi lignin pada pelepah sawit varietas dura

\begin{tabular}{|c|c|c|}
\hline $\begin{array}{l}\text { Lignin Hasil } \\
\text { Penelitian } \\
\left(\mathrm{cm}^{-1}\right)\end{array}$ & $\begin{array}{l}\text { Lignin } \\
\text { Standar } \\
\left(\mathrm{cm}^{-1}\right)\end{array}$ & Gugus Fungsi \\
\hline 3410,15 & $\begin{array}{l}3450 \quad- \\
3400\end{array}$ & $\begin{array}{l}\text { Vibrasi ulur - } \\
\mathrm{OH}\end{array}$ \\
\hline 2937,59 & $\begin{array}{l}2940 \\
2820\end{array}$ & $\begin{array}{l}\text { Vibrasi ulur - } \\
\mathrm{CH}_{3}\end{array}$ \\
\hline 1606,70 & $\begin{array}{l}1715 \\
1710\end{array}$ & $\begin{array}{l}\text { Vibrasi ulur - } \\
\mathrm{C}=\mathrm{O} \text { tak } \\
\text { terkonjugasi }\end{array}$ \\
\hline 1502,55 & $\begin{array}{l}1515 \\
1505 \\
\end{array}$ & $\begin{array}{ll}\text { Vibrasi } & \text { cincin } \\
\text { aromatik } & \\
\end{array}$ \\
\hline 1456,26 & 1470 & Deformasi $\quad \mathrm{C}-\mathrm{H}$ \\
\hline
\end{tabular}




\begin{tabular}{|c|cc|l|}
\hline & 1460 & & asimetris \\
\hline 1273,02 & 1330 & - & Vibrasi cincin \\
& 1325 & & siringil \\
\hline 1220,94 & 1270 & - & Vibrasi cincin \\
& 1265 & & guaiasil \\
\hline 1114,86 & 1085 & - & Deformasi C-H, \\
& 1030 & & C=O \\
\hline 850,61 & 800 & - & C- H Aromatik \\
& 830 & & \\
\hline
\end{tabular}

Sumber data : Hergent (1971) dalam Fengel (1995)

\section{Kandungan Lignin}

Lignin adalah polimer yang komplek dengan berat molekul yang tinggi dan tersusun atas unit-unit fenil propan, walaupun tersusun atas karbon, hydrogen dan oksigen tetapi lignin bukanlah suatu karbohidrat. Lignin terdapat diantara sel-sel, yang berfungsi sebagai pengikat, untuk mengikat sel secara bersamasama. Dalam dinding sel, lignin sangat erat hubungannya dengan selulosa yang mempunyai fungsi untuk memberikan kekuatan pada sel. Hasil analisis varian ( Anova ) pengaruh bagian pelepah sawit varietas dura terhadap nilai kadar Lignin disajikan pada tabel 3 .

Tabel 4. Analisa pengaruh bagian pelepah sawit varietas dura terhadap nilai kadar Lignin

\begin{tabular}{cccc}
\hline Sumber & $\mathrm{db}$ & $\mathrm{F}_{\text {hitung }}$ & Sig. \\
Variasi & & 75.181 & .000 \\
\hline Bagian & 2 & & \\
Pelepah & & & \\
Galat & 6 & & \\
Total & 8 & & \\
koreksi & & & \\
\hline
\end{tabular}

Pada Tabel 4 nilai Hasil Uji Anova menunjukkan ada perbedaan kadar lignin antara posisi bagian pada pelepah sawit varietas Dura, dilihat dari nilai sign lebih kecil dari 0,05 . selanjutnya dilakukan uji t.

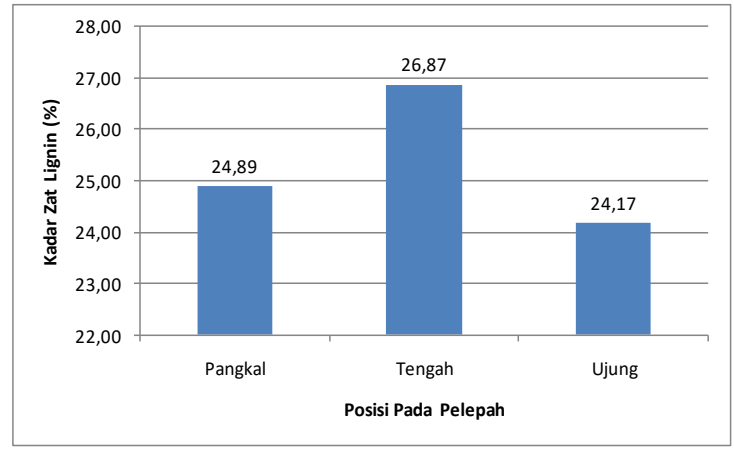

Gambar 2. Variasi Kadar lignin Pelepah Sawit Varietas Dura menurut bagiannya (\%)

Pelepah bagian tengah mempunyai kadar lignin yang lebih besar dibandingkan bagian pangkal dan ujung disebabkan karena sel-sel yang hidup mengalami pertumbuhan yaitu dilihat dari dinding sel yang tampak menggelembung, dinding sel tumbuhan yang telah dewasa terdiri dari banyak bahan penyusun seperti pektin, selulosa, hemiselulosa, kitin, lignin, suberin, kutin, lilin, serta bahan-bahan atau senyawa anorganik lainnya, sehingga pada bagian pangkal umumnya memiliki dinding serabut yang lebih tebal dari pada tengah dan bagian ujung. Kemungkinan bisa terjadi bagian tengah lebih besar kadar ligninnya dibandingkan bagian pangkal dan ujung.

\section{Holoselulosa}

\section{Analisis Holoselulosa Menggunakan FTIR}

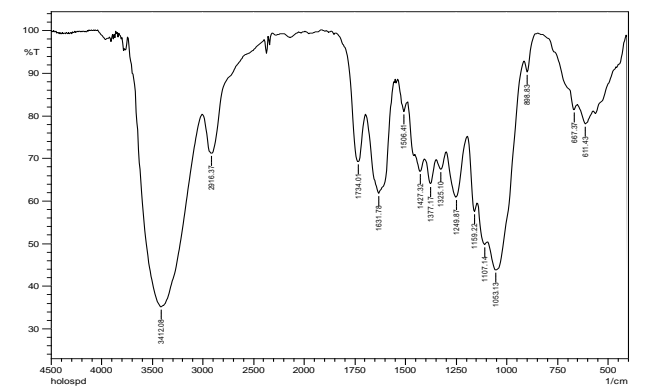

Gambar 3. Holoselulosa Pelepah Sawit varietas Dura Bagian Pangkal Menggunakan FTIR

Hasil analisis FTIR holoselulosa pelepah sawit varietas dura terdapat puncak dengan intensitas kuat pada bilangan gelombang $3412,08 \mathrm{~cm}^{-1}$ menunjukkan adanya gugus hidroksil (-OH), pada daerah 2916,37 $\mathrm{cm}^{-1}$ terdapat gugus fungsi $\mathrm{C}-\mathrm{H}$, pada daerah $1631,78 \mathrm{~cm}^{-1}$ terdapat gugus fungsi $\mathrm{C}=\mathrm{C}$, dan 
terlihat pada daerah bilangan gelombang $1053,13 \mathrm{~cm}^{-1}$ adanya gugus fungsi C-O.

\section{Kandungan Holoselulosa}

Holoselulosa merupakan fraksi total dari karbohidrat yang terdiri dari selulosa dan Hemiselulosa yang dihasilkan setelah lignin dihilangkan dari kayu.

Tabel 5 Analisa pengaruh bagian pelepah sawit varietas dura terhadap nilai kadar holoselulosa

\begin{tabular}{lcccc}
\hline Sumber & $\mathrm{db}$ & $\mathrm{KT}$ & $\mathrm{F}_{\text {hitung }}$ & Sig. \\
\hline Bagian & 2 & 3.041 & 13.278 & .006 \\
$\begin{array}{l}\text { Pelepah } \\
\text { Galat }\end{array}$ & 6 & .229 & & \\
$\begin{array}{l}\text { Total } \\
\text { koreksi }\end{array}$ & 8 & & & \\
\hline
\end{tabular}

Pada Tabel 5 nilai Hasil Uji Anova menunjukkan ada perbedaan kadar lignin antara posisi bagian pada pelepah sawit varietas Dura, dilihat dari nilai sign lebih kecil dari 0,05 . selanjutnya dilakukan uji t.

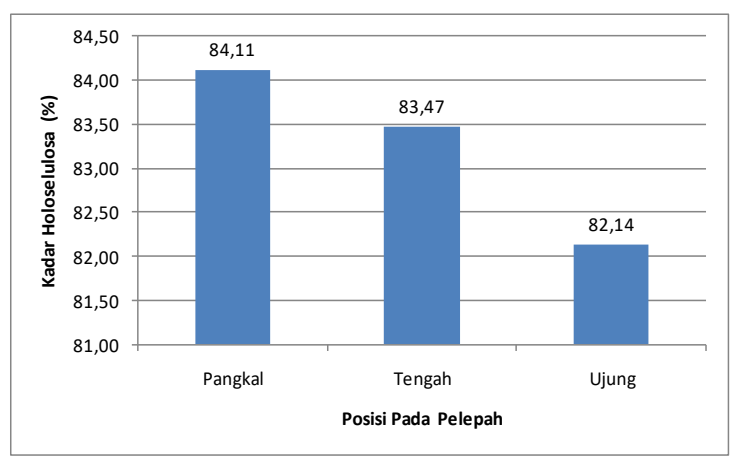

Gambar 4. Variasi holoselulosa Pelepah Sawit Varietas Dura menurut bagiannya (\%)

Pada Gambar 4 menunjukkan bahwa bagian ujung dengan bagian tengah berbeda nyata, bagian ujung dengan pangkal juga berbeda nyata, sedangkan bagian tengah ke bagian pangkal tidak berbeda nyata. Kadar holoselulosa dibagian pangkal nyata lebih besar dari pada bagian ujung tetapi tidak berbeda nyata dengan bagian yang di tengah.Kadar nilai holoselulosa mengalami penurunan dari bagian pangkal, tengah ke bagian ujung, hal ini dikarenakan pada bagian pangkal umumnya memiliki dinding serabut yang lebih tebal daripada bagian tengah dan ujung. Keadaan ini serupa pula dengan yang dilaporkan dalam hasil penelitian dilakukan oleh Panshin dalam Hermawan et al (2014) melaporkan bahwa distribusi holoselulosa pada batang kelapa sawit, baik secara aksial dan radial mempunyai kecenderungan untuk menurun, hal ini disebabkan karena adanya pertumbuhan meninggi yang ditentukan oleh jaringan meristem, sedangkan untuk arah radial disebabka karena pengaruh pertumbuhan sekunder.

$\alpha-$ selulosa

\section{Analisis $\alpha$ - selulosa menggunakan FTIR}

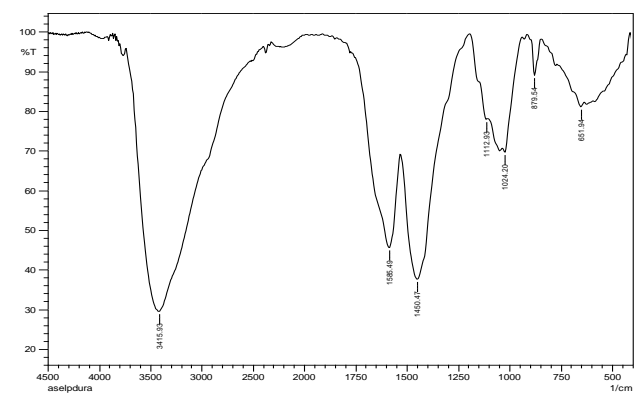

Gambar 5. Hasil Pengukuran $\alpha$-selulosa Pelepah Sawit varietas Dura Bagian Pangkal Menggunakan FTIR

Hasil analisis FTIR $\alpha$-selulosa pelepah sawit varietas dura terdapat puncak dengan intensitas kuat pada bilangan gelombang $3415,93 \mathrm{~cm}^{-1}$ menunjukkan adanya gugus hidroksil (-OH), kemudian teramati puncak serapan pada 1450,47 $\mathrm{cm}^{-1}$ adanya gugus fungsi $\mathrm{C}=\mathrm{C}$ dan pada bilangan gelombang $1024,20 \mathrm{~cm}^{-1}$ menunjukkan adanya gugus fungsi C-O.

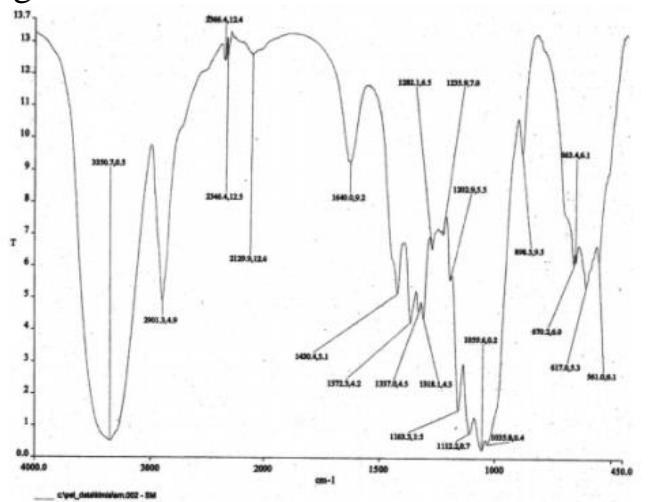

Gambar 6. Spektra FT-IR selulosa standar Sumber data : Monariqsa, dkk. 2012 


\section{Kandungan $\alpha-$ selulosa}

$\alpha$ - selulosa adalah suatu nama yang diberikan pada selulosa murni yang berasal dari tumbuh-tumbuhan dipandang dari kadar larutnya dalam alkali, $\alpha$ - selulosa bukannya senyawa kimia yang sesungguhnya, tetapi merupakan bagian dari selulosa tumbuhtumbuhan (selulosa kayu) yang tidak larut dalam natrium hidroksida kuat.

Tabel 6 Analisa pengaruh bagian pelepah sawit varietas dura terhadap nilai kadar $\alpha$ selulosa

\begin{tabular}{ccccc}
\hline Sumber & $\mathrm{db}$ & $\mathrm{KT}$ & $\mathrm{F}_{\text {hitung }}$ & Sig. \\
\hline Bagian & 2 & .047 & 1.923 & .226 \\
Pelepah & & & & \\
Galat & 6 & .024 & & \\
Total & 8 & & & \\
koreksi & & & & \\
\hline
\end{tabular}

Hasil pada penelitian menunjukkan bahwa tidak adanya perbedaan kadar $\alpha$-selulosa antara bagian pangkal, tengah dan ujung, hal ini mengindikasikan bahwa dalam pemanfaatannya untuk menghasilkan produk, semua bagian dapat dimanfaatkan dan diduga tidak akan menghasilkan perbedaan kualitas.

\section{Penelitian Pendidikan}

Implementasi Video pembelajaran dan LKPD dalam pembelajaran dilakukan untuk mengetahui perbedaan hasil belajar siswa sebelum dan sesudah pembelajaran. Sebelum ditayangkan Video dan diberikan LKPD, siswa diminta untuk mengerjakan soal pretest berbentuk esai sebanyak 5 soal dan soal postest pada akhir pembelajaran dengan jumlah yang sama, yang bertujuan untuk mengetahui peningkatan hasil belajar siswa dengan menggunakan Video pembelajaran dan LKPD.

Tabel 7. Hasil Pretest dan Postest

\begin{tabular}{|c|c|c|c|c|}
\hline & N & Mean & $\begin{array}{c}\text { Std.Dev } \\
\text { iation }\end{array}$ & $\begin{array}{c}\text { Std } \\
\text { Error }\end{array}$ \\
\hline Pretest & 20 & $\begin{array}{c}42.250 \\
0\end{array}$ & $\begin{array}{c}12.9243 \\
8\end{array}$ & $\begin{array}{c}2.8899 \\
8\end{array}$ \\
\hline Postest & 20 & $\begin{array}{c}83.500 \\
0\end{array}$ & 9.33302 & $\begin{array}{c}2.0869 \\
3\end{array}$ \\
\hline
\end{tabular}

Dalam penelitian ini dilakukan dua kali test yaitu pretest dan posttes. Tujuannya adalah untuk mengetahui seberapa besar pengaruh pemberian perlakuan terhadap hasil belajar siswa terhadap aspek berfikir kritis. Soal pretest yang diberikan sama dengan soal postes, bentuk soal yang diberikan adalah soal esai. Dari hasil yang diperoleh terlihat bahwa nilai rata-rata pretes adalah 42,25 dan nilai rata-rata postes adalah 83,35

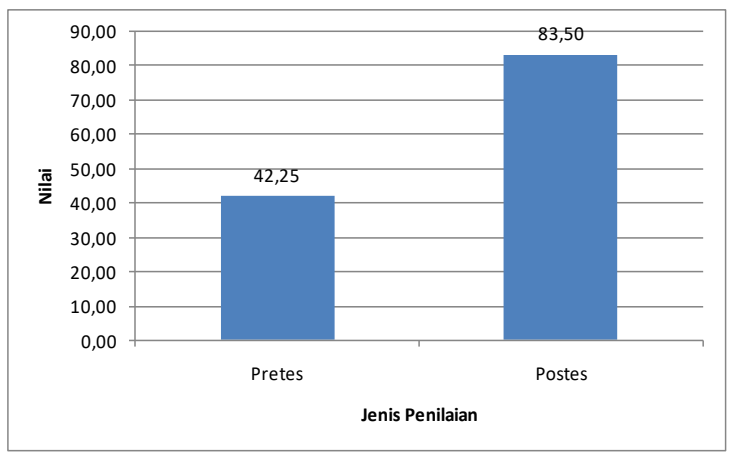

Gambar 6. Rata-rata hasil pretest dan postest

Proses pembelajaran dengan Video Pembelajaran dan LKPD dapat membawa peserta didik untuk bergairah dalam belajar, karena Video pembelajaran memiliki kelebihan antara lain memudahkan pembelajaran dan pencapaian objektif (guru dapat menerangkan tentang suatu konsep yang abstrak atau sukar diterangkan), peserta didik tidak lagi pasif mendengar ceramah dari guru, akan tetapi peserta didik diharapkan aktif dalam proses pembelajaran.

\section{KESIMPULAN}

Dari penelitian ini dapat diambil kesimpulan bahwa kadar komponen kimia dari pangkal, tengah dan ujung secara berturut-turut dari pelepah sawit varietas dura untuk untuk kadar zat ekstraktif 8,92\%, 7,80\%, 7,23\%. Lignin $24,89 \%, \quad 26,87 \%, \quad 24,17 \%$. Holoselulosa 84,11 \%, 83,47 \%, 82,24\% dan $\alpha$-selulosa $45,76 \%, 45,76 \%, 45,54 \%$

Terdapat pengaruh bagian pelepah sawit terhadap nilai kadar ekstraktif, lignin dan holoselulosa, tetapi tidak ditemui pengaruh bagian tersebut terhadap kadar $\alpha$-selulosa.

Kadar ekstraktif bagian pangkal dari pelepah sawit varietas dura secara statistik signifikan lebih besar dari pada bagian tengah dan ujungnya. Bagian tengahnya juga signifikan lebih besar dari pada bagian ujung. Kadar lignin bagian pangkal signifikan lebih 
besar dari pada bagian ujung, sementara bagian tengahnya juga signifikan lebih besar dari pada bagian pangkal dan ujungnya. Untuk kadar holoselulosa, bagian pangkal dan tengah signifikan lebih besar dari pada bagian ujungnya.

Berdasarkan hasil analisis komponen kimia (Lignin, holoselulosa dan $\alpha$-selulosa) menggunakan Spektroskopi FTIR dapat mengindentifikasi gugus fungsi antara lain serapan gugus fungsi (-OH) pada bilangan gelombang antara $3600-2500 \mathrm{~cm}^{-1},(\mathrm{C}-\mathrm{H})$ pada bilangan gelombang $3000-2850 \mathrm{~cm}^{-1}$, ( $\mathrm{C}=\mathrm{C})$ pada bilangan gelombang $1640-1680$ $\mathrm{cm}^{-1}$ dan (C-O) pada bilangan gelombang1300 $-1000 \mathrm{~cm}^{-1}$.

Terdapat perbedaan antara hasil belajar kimia sebelum dan sesudah proses pembelajaran menggunakan video pembelajaran dan LKPD. Rata-rata nilai pretest 42,25 sedangkan rata-rata postest sebesar 83,50.

\section{DAFTAR PUSTAKA}

Anggraini, D., \& Roliadi, H. (2011). Pembuatan pulp dari tandan kosong kelapa sawit untuk karton pada skala usaha kecil. Jurnal Penelitian Hasil Hutan, 29(3), 211-225.

Arikunto, S. 2008. Dasar-Dasar Evaluasi Pendidikan . Bumi Aksara. Jakarta.

Batubara, L. P. (2003). Potensi integrasi peternakan dengan perkebunan kelapa sawit sebagai simpul agribisnis ruminan. Wartazoa, 13(3), 83-91.

Guntoro, S. (2008). Membuat Pakan Ternak dari Limbah Perkebunan. AgroMedia.

Harpendi, R., Padil, P., \& Yelmida, Y. (2014). Proses Pemurnian Selulosa Pelepah Sawit Sebagai Bahan Baku Nitrolesulosa Dengan Variasi pH Dan Konsentrasi H2O2. Jurnal Online Mahasiswa (JOM) Bidang Teknik dan Sains, 1(1), 1-8.

Hermawan, A., Diba, F., Mariani, Y., \& Setyawati, D. (2014). Sifat Kimia Batang Kelapa Sawit (Elaeis Guinensis Jacq) Berdasarkan Letak Ketinggian Dan Kedalaman Batang Chemical Properties Of Oil Palm Trunk (Elaeis Guinensis Jacq) Based On Height And Depth Of Trunk. Jurnal Hutan Lestari, 2(3).
Kartodihardjo, H., \& Supriono, A. (2000). Dampak pembangunan sektoral terhadap konversi dan degradasi hutan alam: kasus pembangunan HTI dan perkebunan di Indonesia. Center for International Forestry Research.

Panshin, A. J., \& Zeeuw, C. D. (1980). Textbook of wood technology. McGraw-Hill Book Co..

Sonnenfeld, D. A. (2000). Developing countries: Contradictions of ecological modernisation: Pulp and paper manufacturing in South-east Asia. Environmental politics, 9(1), 235256.

Syafii, W. (2000). Zat ekstraktif kayu damar laut (Hope spp) dan pengaruhnya terhadap rayap kayu kering Cryptotermes cynocephalus Light. Jurnal Teknologi Hasil Hutan, 13(2), 1-5. 